\title{
Märchen und Erzählungen
}

\author{
der \\ Suaheli
}

von

\section{VELTEN}

Lehrer des Suaheli am Seminar für orientalische Sprachen

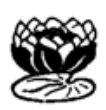

Stuttgart und Berlin

W. SPEMANN

1898 



\section{Ihrer Hoheit \\ der \\ HERZOGIN JOHANN ALBRECHT \\ zII

\author{
Mecklenburg
}

der hohen Gönnerin kolonialer Bestrebungen

mit höchster Erlaubnis

in ehrfurchtsvollster Ergebenheit

gewidmet

vom Verfasser 
